\title{
sciendo
}

\section{The impact of business digitization on the three pillars of sustainable development}

\author{
Paula MUNTEANU \\ School of Advanced Studies of the Romanian Academy (SCOSAAR), Romanian Academy, \\ 13 Septembrie Street, 13, Bucharest, Romania \\ Pma.Munteanu@Gmail.com \\ Laurențiu CIORNEI \\ School of Advanced Studies of the Romanian Academy (SCOSAAR), Romanian Academy, \\ 13 Septembrie Street, 13, Bucharest, Romania \\ Laurentiu.Ciornei@Ince.ro
}

\begin{abstract}
The world is currently facing great challenges generated by the fourth industrial revolution. If the first three major industrial revolutions took place over several centuries, the current revolution, in full swing, is characterized by an alert rhythm, having an exponential evolution, rather than a linear one. Many specialists consider that this is a continuation of the third industrial revolution, started in the sixties of the last century, but the permanent need to adapt and change the business models that characterize daily life determines us to appreciate that they represent the elements of a new, unusual revolution, which will greatly change the face of humanity. Digital technology will bring about essential changes in business, social organization and even current governance models. In this sense, we will approach the digitization of the business from the perspective of the three pillars, social, economic and environment, to conclude to what extent, this new and last revolution adheres to the principles of sustainable development. In this study, we aim to analyze the economic links between the digitization of business and sustainable development in Romania, through an econometric analysis. The results of the econometric analysis will determine to what extent the defining elements of sustainable development will be influenced by this phenomenon. Furthermore, we would like undeline that the fourth industrial revolution, by digitizing business, will affect the three pillars of sustainable development, without mitigation measures which the decision makers should consider, amplifying the phenomenon of social inequity, deepening economic imbalances as a result of the polarization of economic activities, concentrated only in certain regions and irreparably affecting the environment and natural balance, becoming a danger to biodiversity conservation.
\end{abstract}

Keywords: sustainable development, business digitization, social factor, industrial revolution, natural balance and biodiversity.

\section{Introduction}

Nowadays, globalization, even the inverse phenomenon of deglobalization, is confronted with the challenge imposed by sustainable development in the three dimensions, economic, social and environmental, together with the global need for capital and consumer goods, on an ascending trajectory. In order to meet these requirements, the creation of industrial values will have to be oriented towards sustainability. Countries that have understood this, have been oriented early, and have been targeting capital, investing in technology and know-how, so that, at present, the creation of industrial value in developed countries, exactly those countries that have industrialized among the first countries, at the beginning of the last century, is strongly conditioned by the development of the fourth stage of industrialization, the so-called Industry 4.0, marked by digitization. The current theories state that in this stage of industrial development, through digitization, the opportunity to achieve sustainable productions is offered. 
Digitization has a substantial influence on the industry and is based on the establishment of smart factories, intelligent products and intelligent services embedded in an internet of things and services called industrial internet. They in turn entail new business models that offer immense opportunities for sustainable achievement through the use of information and communication technology infrastructure. There is a large process of dematerialization of products and services (Hadad \& Bratianu, 2019). However, from the opportunity to achieve sustainable development, to the achievement of sustainable development, it is a long and difficult path because it involves many sacrifices, most of them social.

In this sense, a greater attention is required in approaching the process of digitization, in order to understand the specificity elements that characterize it in order to formulate those economic theories that will be based on economic models adapted to the times in which we live and which will ultimately constitute, credible sources of economic predictability for creating sustainable development strategies. Moreover, these models must also take into account the phenomenon of globalization, the process of deglobalization, in full progress that does nothing but direct the investment sources to the developed regions, especially to the countries of origin.

\section{Digitizing the business and the three pillars of sustainable development}

\section{The economic pillar}

According to the opinion of some experts, the economic polarization has occurred and now the phenomenon of withdrawal of investments to the countries of origin is in full progress. We are in the full era of post-globalization and digitalization is about to transform production by unifying digital technologies, the internet with the conventional industry. For these reasons, none of the economic models and theories seem to correspond anymore to the current economic reality, especially if we take into account the protectionist policies established by the developed countries and the speed with which the new technologies conquer the world. From this point of view, digitization requires the help and even the creation of new economic theories that correspond to the current economic stage. Without this adaptation, no forecast can be made, given that the defining elements of the current theories do not take into account the factors that characterize the phenomenon of digitization.

\section{The social pillar}

It is certain that the impact of digitalization is overwhelming on the social pillar. As many economists have blamed economic growth in the past if it does not solve the problem of poverty, in our times, if adequate economic models are not found that take into account the current economic context, the phenomenon of population poverty will deepen, a process that is hardly difficult to be irreversible. We speculate that the world of the future is a world of personal capabilities and valences that they will value more than capital, as sources of financing. Until reaching the goals of sustainable development there is a long way to go, given that there are still many more countries in the world where the illiterate population represents a significant share of the total population. The result obtained by Romania in the evaluation of PISA 2018 should also be mentioned here: functional illiteracy is $44 \%$ and Romania occupies the last place in the European Union (47th place in reading and 52nd in mathematics), being the worst result in the last nine years. Education must be adapted to current conditions and the means of achieving sustainable development goals must be reviewed. 
The messages coming from the business environment to the authorities, at least at European level, were aimed increasing the fiscalization that reached a limit of the economic agents' tolerability. In addition, the current phenomenon of digitization has been brought to the attention of the authorities as a generator of layoffs. Moreover, the need for a skilled emplyees has been exacerbated and the authorities are not able to think in perspective and reform the education system.

\section{The environmental pillar}

PICBE | 345

At the global level, digitization aims to produce science and achieve excellence in science to address environmental and societal challenges.

At European level, within the Horizon 2020 program, the Commission has shown its willingness to join industry partners to work together on research and innovation projects through public-private partnerships to identify optimal solutions for future factories that protect the environment by increasing the energy consumption of buildings by increasing the share of green vehicles, Energy-efficient Buildings (EeB), European Green Vehicles Initiative (EGVI), Sustainable Process Industry (SPIRE), etc. In addition to the public-private partnerships established, within the Horizon 2020 program, a series of related sections in the field of sustainable agriculture and forestry, marine research, maritime and bioeconomy, intelligent and integrated green transport, safe, clean and efficient energy, climate action, environment, resource efficiency and raw materials, biodiversity and SMEs innovation were included.

Apart from the three pillars mentioned above, the cultural pillar plays an essential role, considering that it is related to the social factor, although it cannot yet be quantified and introduced into economic theories and models, not being officially included in the pillars of sustainable development. Only a few countries belonging to poorly developed regions have approached the cultural pillar together with the economic, social and environmental pillar as pillars of sustainable development. According to Asadi and Farrokhi, "The present directs the human being towards deceptive and ephemeral ideals.... Mankind can only respond to the crisis of identity and personality regarding the environment and its goods as tradition, religion and history and to follow a correct and adequate model to achieve the mental peace". Digitization is strongly influenced by the cultural factor, as a reaction to stress caused by the origins and mentalities of the human resource.

Taking into consideration the commitments made in the field of sustainable development, in recent years, the European Union has officially recognized the role of corporate social responsibility. Corporate Social Responsibility (CSR) is defined as "the responsibility of companies for their impact on society". Thus, the Directive 2014/95/EU emerged, requiring to companies to draw up a non-financial statement that must contain environmental issues, how business activity impacts the safety and health, the use of renewable and non-renewable energy, the greenhouse gases emissions, water use and air pollution. In this context, achieving the desires that derive from the principles of sustainable development, requires sustained efforts, both from the public authorities, from the industries, from the people and all the factors involved, because digitization is a large process that will cover all areas of activity.

\section{Business digitization and sustainable development in Romania Variables of a potential econometric model}

In order to develop an econometric model that explains the dependency relationship between the business digitization phenomenon and the three pillars of sustainable development, in this study 
we will focus on identifying, explaining and correlating the variables, and in the following studies we will focus on the methodology and results of the econometric model.

\section{Foreign direct investment}

In this study, our focus will be on the description of foreign direct investments, as a determining factor, the independent variable, which has the power to influence both investments in the digitization of business and how this can be done without endangering the sustainable development, as these have been defined in many working agendas.

Why foreign direct investments? Because they are the promoter of developments in the world, considered to be long-term investments that contribute to the consolidation of economies. There are also indirect foreign investments, but these will not be considered as the first factor that has the power to influence the development of digital businesses as they are much more volatile given the fact that the stock market element, usually foreign, is much more volatile, difficult to consider in an econometric model.

Why foreign direct investments? By the 1980s, if commercial loans was the largest source of foreign investment in developing countries and emerging markets offered by banks to companies in foreign countries or the governments of these countries as well as a number of forms of assistance offered by the developed countries, at present, foreign direct investments have increased, being considered to be the determining factor of the economic growth.

However, during the most recent economic crisis, it was found that foreign direct investments also became vulnerable to changes, so there were recorded major fluctuations and exchanges between economic regions, sectors of activity, industries etc. Overall, during the crisis, all the components of the flow of foreign direct investments (capital investments, intra-company loans and reinvested profit) contracted, due to the low value of cross-border mergers and acquisitions as well as the diminished profits of foreign subsidiaries, being affected all three economic sectors: the primary sector, the production sector and the services sector.

Why foreign direct investments? Because, in general, they provide control of most FDI companies, the situation in which the decision on investments in digitizing the business is directly influenced.

\section{Globalization indicators and other variables}

In the current study we propose to approach the globalization indicators as variables that can be made by the decisions of the FDI companies. These indicators are in a continuous dynamic, being permanently improved and revised through the studies and research carried out in this regard.

Globalization Index (KOF)

KOF is that indicator that "reflects the degree of economic, social and political globalization of a country, without making positive or negative evaluations on the result" (Adventage Austria, 2016) being a composite indicator with a total of 23 variables. Romania ranked 36th place in 2016 (out of a total of 207 countries), indicating that the country is open to the outside through all its three major areas (economic, political and social).

Economic Freedom Index (ILE)

ILE explains the relationship between economic freedom and a number of positive economic and social objectives. Economic freedom aims at a clean environment through natural 
balance and biodiversity, poverty eradication, democracy, per capita wealth, human development, etc.

\section{Corruption Perception Index (CPI)}

The CPI reflects the views expressed by business people, analysts from around the world, including experts from the evaluated countries. It is a composite index, which is based on data from corruption surveys conducted by reputable independent institutions.

PICBE | 347

Human Development Index (IDU)

The IDU is used to compare the level of development of a country. It also includes other socio-economic indicators (life expectancy, literacy, education and standard of living) relative to GDP / capita, which only measure material prosperity and is not sufficient. The standard of living of mankind is not given by the size of GDP, it has already been shown that although the level of GDP is increasing, from year to year, the standard of living shows a contrary evolution.

Pollutant emissions

Some direct investments aimed at exploiting the natural resources without taking into account the protection of the environment of the country of destination, of the desire to protect the environment of the country of origin of the capital. It is interesting to see to what extent a correlation can be created between digitizing the business and protecting the environment in order to reduce the level of emissions. The impact of the digitalisation of the business on the sustainable development from the perspective of the environmental pillar can be different, depending on the decisions that the FDI companies consider (of investments in new technologies, of transfer of capital in other countries, of reduction of the logging etc).

\section{Analysis of the potential of developments in the digitization of business in Romania}

Starting from the foreign investments in Romania, as a promoter of sustainable developments, as shown in the table below (Table 1), it is found that, in Romania, the FDI companies registered a negative reinvested profit, starting with the beginning year of the last one crises until 2014 (for seven consecutive years), while the amounts allocated to dividends ranged from $39 \%$ to $47 \%$. Compared to the profit recorded by the FDI companies, the loss recorded by the FDI companies was between $31 \%$ and $108 \%$, the highest weight being reached in 2011 , being continuously decreasing since 2014 and until now, the year 2018 reaching the lowest $31 \%$ weight. It is noted that at the onset of the crisis, the net credit received by the foreign direct investment companies from the foreign direct investors, including within the group, exceeded the loss recorded by the FDI companies.

It should be noted that the value of equity (including accumulated reinvested profit) belonging to non-resident FDI companies was at the end of 2018 of EUR 57479 million (70.85\% of the final balance of FDI), while the net credit received by to these companies from foreign direct investors, including within the group, reached the value of 23,645 million euros, representing 29.15 percent of the final balance of the FDI. The loans received must be repaid according to the agreed terms, compared to the equity that remain available to the companies in order to perform investments. 
Table 1. Statement of Profit, Dividends, Losses and Reinvested Profit (FDI companies) and globalization indicators

\begin{tabular}{|c|c|c|c|c|c|c|c|c|c|}
\hline $\begin{array}{c}\text { Yea } \\
\mathrm{r}\end{array}$ & $\begin{array}{c}\text { Profit } \\
\text { (mil.EUR } \\
\text { ) }\end{array}$ & $\begin{array}{l}\text { Reinvested } \\
\text { Profit (mil } \\
\text { EUR) }\end{array}$ & $\begin{array}{l}\text { Dividends } \\
\text { (Mil.EUR } \\
\text { ) }\end{array}$ & $\begin{array}{l}\text { Losses } \\
\text { (mil. } \\
\text { EUR) }\end{array}$ & $\begin{array}{c}\text { Loans } \\
\text { (mil.EUR } \\
\text { ) }\end{array}$ & $\mathrm{KOF}$ & ILE & IPC & IDU \\
\hline 2008 & 6.412 & -392 & 2.696 & 4.108 & 4.623 & 69,22 & 61,7 & 3,8 & 0,795 \\
\hline 2009 & 4.496 & -1.389 & 1.608 & 4.277 & 1.759 & 68,11 & 63,2 & 3,8 & 0,798 \\
\hline 2010 & 4.222 & -2.243 & 1.970 & 4.495 & 396 & 68,7 & 64,2 & 3,7 & 0,797 \\
\hline 2011 & 4.710 & -2.497 & 2.075 & 5.132 & 303 & 69,76 & 64,7 & 3,6 & 0,798 \\
\hline 2012 & 4.691 & -1.881 & 2.212 & 4.360 & 1.343 & 71,14 & 64,4 & 4,4 & 0,795 \\
\hline 2013 & 5.504 & -337 & 2.287 & 3.554 & 285 & 71,29 & 65,1 & 4,3 & 0,8 \\
\hline 2014 & 5.518 & -1.376 & 2.176 & 4.718 & -425 & 71,09 & 65,5 & 4,3 & 0,807 \\
\hline 2015 & 6.038 & 510 & 2.399 & 3.129 & -134 & 71,7 & 66,6 & 4,6 & 0,813 \\
\hline 2016 & 7.410 & 1.138 & 3.149 & 3.123 & 176 & 71,92 & 65,6 & 4,8 & 0,815 \\
\hline 2017 & 8.068 & 1.733 & 3.526 & 2.809 & 829 & 72,11 & 69,7 & 4,8 & 0,816 \\
\hline 2018 & 8.930 & 2.573 & 3.551 & 2.807 & -280 & & 69,4 & & \\
\hline
\end{tabular}

Source: processing of authors based on data collected from the NBR Reports on FDI

Or, sustainable development means that funds should be kept for the longest time available to companies and reinvested so as to produce truly sustainable development. Especially, if in the context of these sustainable developments we consider the phenomenon of digitization, it requires that large amounts be directed to research, innovation and the acquisition of new technologies, and this aspect we notice that contradicts the way of profit distribution in Romania.

Moreover, it can be seen that in Romania, the evolution of foreign direct investments began to show a downward trajectory (Figure 1). However, this trend of decreasing foreign direct investment corresponds to the one generally expressed by European countries (Figure 2), with the exception of the Netherlands which has an upward trend, which can be explained by the fiscal facilities that this country practices and which allow the opening of some new companies through foreign investment.

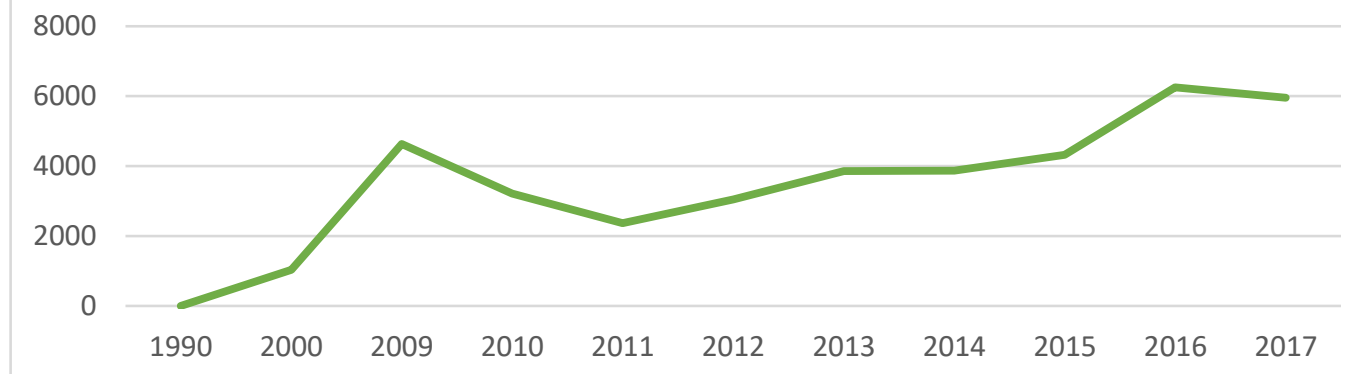

Figure 1. Evolution of foreign direct investments in Romania (mil USD)

Source: own calculations based on data from https://databank.worldbank.org/data 


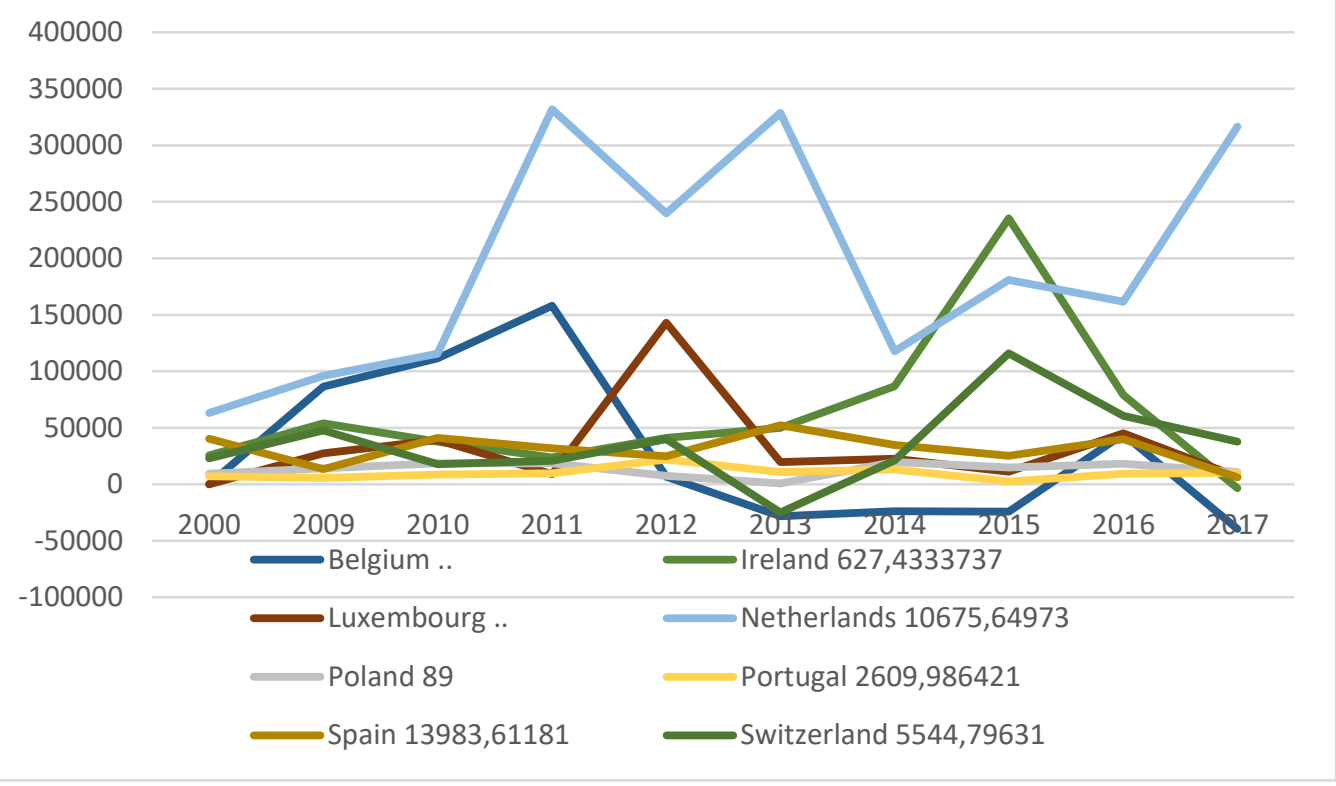

PICBE | 349

Figure 2. Evolution of foreign direct investment in Europe (USD million)

Source: own calculations based on data from https://databank.worldbank.org/data

The frequent increase of the capital transfers from one country to another and the increase of the active role manifested by foreigners in the management process has as a consequence the decrease of the decisional role of the countries of destination of these investments. In this way, foreign investments can lead to imbalances in national security, if risk mitigation measures are not taken in time.

Based on the data in Table 1, we propose to determine the correlations between the results recorded by the Romanian FDI companies and the indicators that measure the level of sustainable development of the country in the context of globalization, factors that could influence the business digitization phenomenon.

Table 2 - Correlation between variables (Author's processing in Eviews11)

\begin{tabular}{|c|c|c|c|c|c|c|c|c|c|}
\hline Probability & PROFIT & INVESTED_PROI & DIVIDENDS & LOANS & LOSSES & IDU & ILE & CPI & KOF \\
\hline \multirow[t]{2}{*}{ PROFIT } & 1 & & & & & & & & \\
\hline & ---- & & & & & & & & \\
\hline \multirow[t]{2}{*}{ REINVESTED_PRC } & -0.008422 & 1 & & & & & & & \\
\hline & 0.9816 & ----- & & & & & & & \\
\hline \multirow[t]{2}{*}{ DIVIDENDS } & 0.957716 & -0.056498 & 1 & & & & & & \\
\hline & 0.0000 & 0.8768 & ----- & & & & & & \\
\hline \multirow{2}{*}{ LOANS } & 0.342152 & -0.180740 & 0.484105 & 1 & & & & & \\
\hline & 0.3332 & 0.6173 & 0.1562 & ----- & & & & & \\
\hline \multirow[t]{2}{*}{ LOSSES } & -0.796060 & -0.209640 & -0.739279 & -0.369076 & 1 & & & & \\
\hline & 0.0059 & 0.5610 & 0.0146 & 0.2939 & ----- & & & & \\
\hline \multirow[t]{2}{*}{ IDU } & 0.780594 & 0.510882 & 0.694380 & 0.171926 & -0.745191 & 1 & & & \\
\hline & 0.0077 & 0.1313 & 0.0259 & 0.6348 & 0.0134 & ----- & & & \\
\hline \multirow[t]{2}{*}{ ILE } & 0.590890 & 0.458247 & 0.607338 & 0.474303 & -0.608485 & 0.815260 & 1 & & \\
\hline & 0.0720 & 0.1829 & 0.0626 & 0.1661 & 0.0619 & 0.0041 & ----- & & \\
\hline \multirow[t]{2}{*}{ CPI } & 0.734724 & 0.337796 & 0.709477 & 0.099657 & -0.808527 & 0.822018 & 0.733041 & 1 & \\
\hline & 0.0155 & 0.3398 & 0.0216 & 0.7842 & 0.0046 & 0.0035 & 0.0159 & ---- & \\
\hline \multirow[t]{2}{*}{ KOF } & 0.668155 & 0.276172 & 0.686039 & 0.101534 & -0.642764 & 0.741748 & 0.748615 & 0.912509 & 1 \\
\hline & 0.0347 & 0.4399 & 0.0285 & 0.7802 & 0.0450 & 0.0141 & 0.0127 & 0.0002 & $-\ldots---$ \\
\hline
\end{tabular}

There is a direct and high-intensity link between IDU and profit obtained by the FDI companies (the probability that the linear correlation coefficient estimator is zero is 0,0077), 
respectively direct and medium-intensity link with dividends (the probability that the linear correlation coefficient estimator is zero is 0,0259 ) and indirect and high-intensity link with losses (the probability that the linear correlation coefficient estimator is zero is 0,0134 ).

The Corruption Perception Index (CPI) has direct and medium-intensity links with profit obtained by the FDI companies, distributed dividends and ILE (probability less than 0.05), respectively, a direct and high-intensity link with IDU, an indirect and high-intensity link with losses (probability less than 0.05) and direct and low-intensity link with reinvested profit which explains the distribution of the profit to the shareholders, at the expense of the reinvestment, is caused by the corruption in Romania.

The globalization index (KOF) has a direct and medium-intensity link with profit obtained by the FDI companies, distributed dividends, IDU and ILE, respectively, a direct and high-intensity link with CPI and a direct and low-intensity link with reinvested profit and loans.

Linear correlation coefficients do not identify a link between reinvested profit/loans and all indicators (the probability attached to the null hypothesis is much higher than the standard prognosis of 0.05). Otherwise, there is either no link between the variables or the links are of low intensity, whether they are direct or indirect. These relationships could be real or the statistical correlations could be altered by the small number of records. We can advance the idea that the digitization of the business is influenced by the level of development of the country and its economic freedom and targets a number of economic and social objectives.

\section{Conclusions}

In the real economy, a phenomenon cannot be only explained by the influence of a single determining factor or of several factors only, as we have listed above. There are other factors, more or less important causes that can influence the dependent variable, the determining factor being able to manifest itself differently depending on the degree of stability of the other factors. The conclusions can be drawn only after analyzing the correlations of the data series, at which time those factors/causes can be added/eliminated and a suitable econometric model created.

In order to build the working hypotheses, the model will have to start from the afore mentioned results and take into account those relevant elements.

Romania needs a major change of approach regarding foreign investments, as a determining factor influencing sustainable developments. The fact that reinvested profit is not a priority of FDI companies should worry about the political factor to invest in early education, in the sense of training young people in specializations that correspond to the changes brought about by the digitization of businesses in order to prevent the increase in layoffs as a result of repatriation of profits and technological developments in the countries of origin to the detriment of the host countries.

Given the previously identified links between ILE (clean environment through natural balance and biodiversity, poverty eradication, democracy, per capita wealth, human development) and reinvested profit, decision-makers need to be much more involved in protecting the environment, by defining to those levers of rational exploitation of renewable and non-renewable natural resources and by encouraging the acquisition of new technologies that reduce the negative externalities caused (on biodiversity, human health and life in general). 
The financial incentives that Romania could use to encourage the orientation of foreign direct investment/reinvested profit in certain digital developments are meant to have a positive impact on sustainable developments.

Given the rapid pace of digital development, in order to explain the dependency relationship between the business digitization phenomenon and the three pillars of sustainable development and to make certain forecasts, the econometric model should contain an additional element, a digital multiplier, a new term that we dare to propose in this study. We need to define a methodology for calculating it, and here we are already in the sphere of economic theories that are no longer current and which should be redefined, so that they correspond to the times in which we live.

In this regard, in the following articles, we will focus our study on those determinants and the calculation methodology, and the results will confirm or disprove our theory that the positive or negative effects of digitizing the business is directly influenced by the size of the reinvested profit.

\section{References}

Asadi S., Farrokhi M. (2015). The challenges of sustainable development and architecture, International Journal of Science, Technology and Society. 014; 3(2-1): 11-17, Published online February 9, 2015 (http://www.sciencepublishinggroup.com/j/ijsts)

Hadad, S., \& Bratianu, C. (2019). Dematerialization of banking products and services in the digital era. Management \& Marketing. Challenges for the Knowledge Society, 14(3), 318-337.

Jula Dorin, Jula Nicolae-Marius, Econometrie, Editura Mustang, Bucuresti, 2019. Şerbu, S. G. (2007). Investiţiile străine directe. Determinanţi, efecte şi politici de promovare, Casa Cărţii de Ştiinţă, Cluj-Napoca, 2007.

Zaman, Gh, Geamănu, M., Eficienţa economică, Editura Fundaţiei România de Mâine, Bucureşti, 2006, 180 p.; Eficienţa economică în condiţiile dezvoltării durabile, Editura Fundaţiei România de Mâine, Bucureşti, 2014, 191.

Directive 2014/95/EU of the European Parliament and of the Council of 22 October 2014 amending Directive 2013/34/EU as regards the disclosure of non-financial information and diversity by certain companies and large groups.

Biblioteca Digitala, Retrieved from: http:/www.biblioteca-digitala.ase.ro/biblioteca/

Clarivate, Retrieved from: https://clarivate.com/webofsciencegroup/campaigns/sustainabledevelopment-goals/

European Commission, Retrieved from: https://ec.europa.eu/info/strategy/internationalstrategies/sustainable-development-goals/eu-approach-sustainable-development_ro

Data Bank, Retrieved from: https://databank.worldbank.org/data

MAE, Retrieved from: https://www.mae.ro/node/35919

UN, Retrieved from: https://www.un.org/sustainabledevelopment/sustainable-development-goals/

UN, Retrieved from: https:/www.un.org/sustainabledevelopment/sustainable-development-goals/

UNCTAD, Retrieved from: https://unctad.org/en/PublicationsLibrary/wir2018_en.pdf

UNCTAD, Retrieved from: https://unctad.org/en/docs/wir2009_en.pdf

We Forum, Retrieved from: https://www.weforum.org/reports/the-global-risks-report-2019 